\title{
Mexico-US local transborder micro-business methods resisting border travel restrictions in 2020
}

\author{
Mitxy Mabel Meneses Gutiérrez ${ }^{1}$
}

Accepted: 19 April 2021 / Published online: 8 June 2021

(c) The Author(s), under exclusive licence to Springer Nature Limited 2021

It has always been hard to fully explain my hometown, my upbringing, and the reason for my Spanglish. I was raised in the border city of Mexicali, adjacent to Calexico, California. As a child, I thought cities can be divided into two by a fence or can even comprise two countries. As I grew, I began to acknowledge the unique dynamic I had been experiencing my entire life. Some activities were on the Mexican side of the border and some others on the US side. For instance, I went to school on the Mexican side. However, grocery shopping was always conducted on the US side. Sunday trips and family meals also happened on the US side. If we needed toilet paper, snacks, or any other item for school or the household, we would cross to Calexico. In this same sense, my friends lived on both sides and enjoyed what these cities offered. Options were never limited to just the country of my residency. Such a dynamic is typical and an essential element in my life and shared by other residents with a visa or passport. Unfortunately, everything changed on 21 March 2020, when border closures and limited traveling was announced because of the pandemic.

The COVID-19 pandemic affected the entire world in different ways, depending on specific regional contexts. In the case of the US-Mexico border region, the disruptions stemmed from respective national policies and agreed-on international travel restrictions causing the most prolonged border closure since the border's full establishment in 1854 . For approximately fourteen million people residing in adjacent cities located on both sides of the border, this interplay of domestic and international policies affected everyone's lives differently. In the case of some Mexican residents, such as me, crossing the border to shop for essential goods in the US or visit friends was no longer possible. At least, that is what most people in such a condition thought at first. But the historical interconnectedness of the border region and its dynamics adapted to the new glocal normality.

The US-Mexico border region today comprises ten states: the Mexican states of Baja California, Sonora, Chihuahua, Tamaulipas, Nuevo Leon, Coahuila, and the US states of California, Arizona, New Mexico, and Texas (Ganster and Lorey 2016).

Mitxy Mabel Meneses Gutiérrez

M.menesesg@gold.ac.uk; Mabel.meneses9@gmail.com

1 University of London, London, UK 
This border region's total population is approximately fourteen million people, with 7.3 million living in the United States and 6.8 million in Mexico. The region also holds fifteen pairs of border "sister cities" inhabited by $90 \%$ of the border population (USEPA and SEMARNAT 2020), including Tijuana-San Diego. These border cities have two land ports of entry, San Ysidro and Otay Mesa. San Ysidro has consistently been the border port most crossed by those with legal documentation, experiencing approximately 25,000 pedestrian crossings and 50,000 vehicle crossings per day (USCBP 2019) up to the year 2019. The second set of sister cities in the California-Baja California border is Mexicali-Calexico, holding two ports of entry, Calexico and Calexico East. The Calexico port has been the fourth most crossed of the US-Mexico border ports, with a total of 12,713,669 documented crossings of pedestrians and personal vehicle passengers in 2019 (USCBP 2019). These numbers reflect the regular crossing dynamic, since Mexicali has a population of only 1,049,792 (INEGI 2020). This number of documented border crossings reflects a dynamic region with unique characteristics demonstrating the level of interconnectedness of the border, particularly in Mexicali-Calexico.

The name Mexicali is a composition of the words Mexico and California. Likewise, the name of Calexico, the adjacent city, is the combination of the words California and Mexico. A dotted line in Mexicali's city seal represents the border, which is of relevance to the city. The Mexican flag is included in Calexico city seal, together with the legend "Where California and Mexico Meet." Such official symbols show how deeply connected both cities are, sometimes referred to as twin cities (Gildersleeve 1979; Kearney and Knopp 1995; Alegría 2012). Understanding the historical link between Mexicali and Calexico is essential when analyzing contemporary local border-crossing practices incorporated into the life of those in the border population with a US visa or passport. However, the year of travel restrictions applied to land ports of entry by the COVID-19 pandemic affected that local transborder dynamic.

On 21 March 2020, the Mexican and US governments announced that the border they share would be limited to only essential travelers. That is, US nationals, people with lawful working and resident permits, students, and truck and train drivers. Such measures also affected trade. Compared with data from 2019, during 2020, entries of passengers from all modes of transportation decreased $42 \%$, while trade entry decreased by just $8 \%$ (USCBP 2021). In the specific case of Mexicali, crossings of pedestrians and private car passengers decreased by $45 \%$ during 2020 compared with the numbers for 2019 (USCBP 2020). Although the economic losses in Calexico due to travel restrictions have not yet been published, it is safe to say that it will be millions of US dollars, mainly from retail and supermarket trade. For instance, in 2019, the Tijuana-San Diego port of entry was closed for several hours, causing a loss of 5.9 million US dollars to the local San Diego economy (Ojeda 2018). The reason for closing the border was the clash between US Customs and Border Protection officers and members of the migrant caravan from Central America. Nonetheless, the border population has adapted to the new extended temporary measures and developed mechanisms to continue having access to US goods, which I was able to experience in Mexicali during the summer of 2020. 
When education classes at all levels in the United Kingdom migrated to virtual platforms, I decided to travel back from London to Mexicali and spend the next critical couple of months with my family. My $\mathrm{PhD}$ research of transborder practices at the Mexico-US border allowed me to continue to analyse border interactions during border closures. At first, it was thought that the limited entries to the US would be for only a few months, beginning in March. Nevertheless, some people prepared and bought months' worth of goods in the United States. By July, different local mechanisms for shopping in the US had arisen, which I had the opportunity to use since I needed some goods "from the other side." But I was also very interested to see how these newly established methods for shopping for goods from Calexico would work.

As mentioned, "essential travelers" hold a US passport, resident permit, or student visa. Also, train drivers can cross to the United States. This meant that those binational residents could continue to cross the border as usual. Such "freedom of mobility" represented a business opportunity for the group. It is important to underscore that such freedom of mobility does not come without inconveniences. For instance, waiting times to cross the border increased as the number of US Customs and Border Protection officers available for processing travel entries decreased. This fact was observable in the number of lanes that were open, compared to pre-pandemic normality. Locals discuss such issues through Facebook groups, stating that it can take up to three hours in northbound crossing through the Mexicali-Calexico port of entry. Such waiting times are included in the overall fee charged, using the new transborder shopping methods, which I identified as the Warehouse method and the Shopping and Errands method.

Both of the shopping methods I used shared things in common. For instance, they required some pre-research or pre-purchase from the interested customer. The Warehouse method included parcels received in the home of an entrepreneur in the United States, which then crossed the border once a week and were delivered to a Mexicali home address familiar to the entrepreneur. Once the packages were in Mexicali, the customer could pick them up from their location. The entrepreneur would not go to any shop or handle cash directly. The standard fee was $20 \%$ of the total of the purchase delivered to his home. On one occasion, I bought a pair of shoes directly on a website that cost me approximately 80 US dollars, including delivery fees. The commission had to be transferred to the entrepreneur's account, which was $20 \%$ of my purchase costs. The commission also included the return or exchange of goods if needed, meaning he would post the package back to the retailer in the United States. The reason for calling it the Warehouse method is because this person just receives the parcels in the US and crosses them over to Mexicali.

The second method I call the Shopping and Errands method. This method was conducted by a woman and offered more services. For instance, I sent her a list of goods I wanted to buy from a shop in Calexico that were available in store as I had previously confimed through its website. Then she calculated the price plus tax and sent me an Excel sheet with the price breakdowns. The total amount of the purchase had to be paid in cash. In case she could not find the requested products, she would look for them in two other similar stores. Another option was to have the products paid for and ready to collect in the store directly, in which case she could pick them up on specific dates and times. The only items that she would not bring over were 
technology-related, as these are subject to importation fees, and not declaring them at the port of entry back to Mexico could have monetary repercussions. An important consideration was to provide her with reusable bags for the requested shopping. If not, extra money was requested.

Moreover, she would also go to PO boxes in Calexico. It is a widespread practice for people living in Mexicali to rent a monthly PO box address in Calexico, as I did. Holding a PO box address allows for cheaper national and international purchases, serves as an address for opening US bank accounts, and provides other services. In such cases, the customer dropped off the PO box key with the woman, who would bring back to Mexicali the correspondence and packages. In all cases, the customers were required to pick the things up from her house on Tuesdays after six in the afternoon. When I went to pick up my requested shopping, at least five other customers were in line outside her house, and more arrived as I was leaving with my goods. In my case, I paid eight US dollars for the full service, plus the total costs of the goods solicited. I was very impressed by the service's convenience and the price, considering the commuting and shopping needed.

After I returned to London in August 2020, many more of these services arose in Mexicali. Today, customers on the Mexican side of the border can choose which service works better based on needs, commission, dates for delivery in Mexicali, online purchase, and so on. It has become common to know someone that crosses goods on request for a commission or payment. In one case, the transborder person conducting the business accepts discounts or deals on products as payment (for instance, buy one and get $50 \%$ off on the second types of deals). The business runner would buy the discounted product either for himself or to resell it afterward. Moreover, younger transborder residents are getting involved with these arrangements to support their economy and studies. Many of these available mechanisms are openly advertised on local Facebook pages. It was truly interesting to observe new local economic solutions connecting both sides of the border to maintain some of the old normality to a certain extent. In the future, it would be important to analyze these micro binational business ventures in intersection with traditional gender roles, global economic hardship, and a possible demographic boom of binational births.

Overall, the adaptive capacities of the border population never ceased to amaze me. Locals managed to keep shopping for goods on their favourite stores in the US with the help of a binational intermediator able to navigate current land border travel restrictions. Retailers, businesses, and shops on both sides of the border have suffered severe economic damage. It is yet to be seen whether they will recover once the border becomes open for nonessential travelers. Another element to consider for the "new border normality," once all restrictions are lifted, is the fact that some populations are now accustomed to the goods available on their side of the border, changing traditional patterns of local shopping. It will be interesting to see whether these methods manage to stay active after the border is open, as they have proven to be an alternative for those who cannot cross it or do not want to because of long waiting times and time constraints. The new local border economic panorama is yet to be seen; however, this border has always been a region for commercial opportunities. Even with border crossing restrictions, local transborder business solutions managed to arise. 


\section{References}

Alegría, T. 2012. The Transborder Metropolis in Question: The Case of Tijuana and San Diego. In Tijuana Dreaming: Life and Art at the Global Border, ed. Josh Kun and Fiamma Montezemolo. Durham, NC: Duke University Press.

Ganster, P., and D. Lorey. 2016. The U.S. Mexican Border Today: Conflict and Cooperation in Historical Perspective. London: Rowman and Littlefield.

Gildersleeve, C. 1979. The International Border City: Urban Spatial Organization in a Context of Two Cultures along the United States-Mexico Boundary. PhD diss., Lincoln, University of Nebraska.

INEGI. 2020. Panorama Sociodemografico de Mexico 2020. Baja California. https://www.inegi.org.mx/ contenidos/productos/prod_serv/contenidos/espanol/bvinegi/productos/nueva_estruc/7028251977 35.pdf.

Kearney, M., and A. Knopp. 1995. Border Cuates: A History of the U.S.-Mexican Twin Cities. Austin, TX: Eakin Press.

Ojeda, A. 2018. Sunday Border Closure Costs San Ysidro Businesses \$5.3 million. San Diego NBC, 26 November. https://www.nbcsandiego.com/news/local/sunday-border-closure-costs-san-ysidro-busin esses-53-million/167919/.

USCBP (US Customs and Border Protection). 2019. On a Typical Day in Fiscal Year 2019. https://www. cbp.gov/newsroom/stats/typical-day-fy2019. Accessed 7 March 2021.

USCBP (US Customs and Border Protection). 2020. On a Typical Day in Fiscal Year 2020. https://www. cbp.gov/newsroom/stats/typical-day-fy2020. Accessed 7 March 2021.

USCBP (US Customs and Border Protection). 2021. CBP Trade and Travel Report, Fiscal Year 2020. February. https://www.cbp.gov/sites/default/files/assets/documents/2021-Feb/CBP-FY2020-Tradeand-Travel-Report.pdf.

USEPA and SEMARNAT (United States Environmental Protection Agency and SEMARNAT). Border 2020: U.S.-Mexico Environmental Program. https://www.epa.gov/sites/production/files/documents/ frontera2020.pdf.

Publisher's Note Springer Nature remains neutral with regard to jurisdictional claims in published maps and institutional affiliations.

Mitxy Mabel Meneses Gutiérrez is a PhD candidate in politics at Goldsmiths, University of London, funded by CONACYT. Her research focuses on transborder practices and policy implications at the CaliBaja region. She holds a B.A. in politics from ITESO, Mexico, and a master's degree in international politics from Universidad Complutense de Madrid, Spain. Her work focuses on migration, education, international cooperation and transborderism. Her professional experience includes working with the International Organization for Migration and the Mexican Secretariat of Public Education. 